\title{
ASSESSMENT OF SOWING QUALITY OF RADISH SEEDS WITH WORKING UNIT OF PNEUMATIC SEEDER
}

\author{
Józef Kowalczuka , Janusz Zarajczyk ${ }^{\mathrm{a}}$, Jarosław Tatarczak ${ }^{\mathrm{a}}$, Ignacy Niedziółka \\ Marek Szmigielski ${ }^{\mathrm{a}}$, Karol Zarajczyk ${ }^{\mathrm{b}}$, Krzysztof Kowalik ${ }^{\mathrm{b}}$ \\ ${ }^{a}$ Department of Agricultural, Forestry and Transport Machines, University of Life Sciences in Lublin \\ ${ }^{\mathrm{b}}$ Ursus S.A. \\ *Corresponding author: e-mail: janusz.zarajczyk@up.lublin.pl

\begin{tabular}{|c|c|}
\hline ARTICLE INFO & ABSTRACT \\
\hline $\begin{array}{l}\text { Article history: } \\
\text { Received: July } 2017 \\
\text { Received in the revised form: } \\
\text { August } 2017 \\
\text { Accepted: September } 2017 \\
\end{array}$ & $\begin{array}{l}\text { The objective of the research was assessment of the sowing quality of } \\
\text { radish seeds with the sowing unit of "MAX PNEUAMTIC" S } 156 \\
\text { pneumatic seeder. Tests were carried out on the original laboratory } \\
\text { stand. They proved that at the assumed range of the working speed } \\
\text { within } 2.5 \text { to } 4.0 \mathrm{~km} \cdot \mathrm{h}^{-1} \text { and rotations of the sowing disc between } 23\end{array}$ \\
\hline $\begin{array}{l}\text { Key words: } \\
\text { seeds, } \\
\text { radish, } \\
\text { point sowing, } \\
\text { quality }\end{array}$ & $\begin{array}{l}\text { and } 37 \mathrm{rot} \cdot \mathrm{min}^{-1} \text {, the most favourable results concerning precision of } \\
\text { seeds spacing in a row were obtained at the speed between } 2.5 \text { and } 3.0 \\
\mathrm{~km} \cdot \mathrm{h}^{-1} \text {. The increase of the speed above } 3.0 \mathrm{~km} \cdot \mathrm{h}^{-1} \text { caused deteriora- } \\
\text { tion of the seeds sowing quality through statistically significant reduc- } \\
\text { tion of the single sowing participation and the increase of the empty } \\
\text { sowings participation. }\end{array}$ \\
\hline
\end{tabular}

\section{Introduction and objective of the paper}

Radish is a plant belonging to Brassicaceae family, of the moderate climate with a short period of vegetation. It requires fertile and humus soils; it is the most often cultivated in the early spring and autumn period (Born et al., 1984).

Radish varieties differ with the shape of the swollen tap roots, their colour, firmness, pulp colour and characteristic taste. The shape of the swollen tap root may be globular, tapering or cylindrical. Varieties may differ with resistance to the so-called pithing and cracking of roots (Kołota et al., 2007; Nieć, 1984).

High yield is obtained as a result of proper cultivation, crop protection, fertilization and precise sowing in determined, unit distance in a row to the right depth (DobrowskaKopecka et al., 1999).

The mentioned conditions may be met by sowing radish seeds with precise seeders. One of such seeders is a pneumatic seeder equipped with disc sowing units. It is the most often used in big farms which deal with horticultural production.

The objective of the research was assessment of the sowing quality of Saxa Polana radish seeds with the sowing unit of "MAX PNEUAMTIC" S 156 pneumatic seeder. Measurements were taken in laboratory conditions on a special test stand (Fig. 1). 


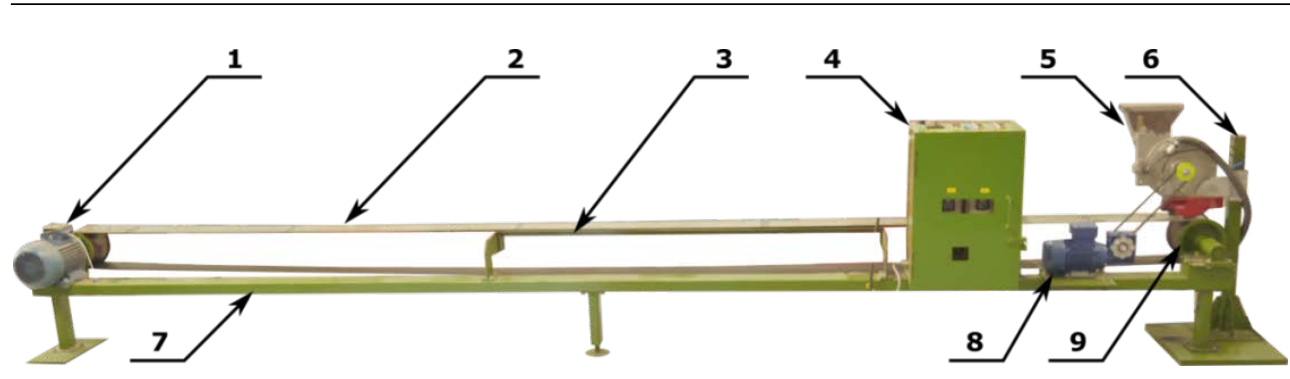

Figure 1. Test stand: 1 - electric engine of the adhesive belt drive, 2 - adhesive belt, 3 - adhesive belt lead, 4 - frequency converters 5 - sowing unit, 6 - sowing unit support, 7 - stand frame, 8 - electric engine of the sowing unit drive, 9 - tension roller of adhesive belt

Adhesive belt is one of the elements of the test stand. It bears a linear scale (spacing of $1 \mathrm{~mm}$ ) which enables measurement of the distance between the sown seeds. The belt is spread between two belt wheels and driven by an electric engine. Engine rotations are controlled with a frequency converter. A working section of the investigated seeder was mounted directly over the belt. The disc of the sowing unit was driven with the electric engine and its rotations were controlled with the frequency converter. Such solution of the drive enabled independent and gradeless regulation of the speed of the belt and rotations of the sowing disc. Table 1 presents working parameters of the test stand.

Table 1.

Working parameters which may be obtained on the test stand

\begin{tabular}{lccc}
\hline Parameter & Unit of measure & & Value \\
\hline Tape speed & $\left(\mathrm{km} \cdot \mathrm{h}^{-1}\right)$ & $\mathrm{min}$. & 1.44 \\
& $\left(\mathrm{~km} \cdot \mathrm{h}^{-1}\right)$ & $\max$. & 10.0 \\
Resolution of the setpoint of the belt speed & $\left(\mathrm{km} \cdot \mathrm{h}^{-1}\right)$ & & 0.23 \\
Number of disc rotations & $\left(\mathrm{rot} \cdot \mathrm{min}^{-1}\right)$ & $\min$. & 0.07 \\
Resolution of the setpoint of disc rotations & $\left(\mathrm{rot} \cdot \mathrm{min}^{-1}\right)$ & $\max$. & 59.0 \\
Overpressure & $\left(\mathrm{rot} \cdot \mathrm{min}^{-1}\right)$ & & 0.059 \\
Underpressure & $(\mathrm{MPa})$ & & up to 5.0 \\
Belt length & $(\mathrm{kPa})$ & & up to 3.0 \\
Belt width & $(\mathrm{m})$ & & 10.0 \\
\hline
\end{tabular}

The test stand was used to take measurements concerning the impact of the working unit speed and rotations of the sowing disc on the sowing quality of radish seeds.

In the recent years, inter alia, Banasiak and Michalak (2000), Przybył and Błaszczak (2000); Karayel D. et al., (2004); Zhao et al., (2010); Yazgi A., Degirmencioglu (2007); 
Assessment of sowing...

Gaikwad B.B, Sirohi N.P.S. (2008); Markowski et al., (2012); Kaur (2013) have dealt with the subject of precise sowing.

\section{Methodology and conditions of research}

Assessment of the radish sowing quality with the working unit of "MAX PNEUAMTIC" S 156 seeder was carried out based on the methodology included in the standard ISO 7256/1-1984 (E).

According to the producer's recommendations, a seeder disc with 60 openings with 2 $\mathrm{mm}$ diameter distributed in two rows placed every $15 \mathrm{~mm}$ were used for sowing radish seeds. Saxa Polana radish seeds, neither calibrated nor encapsulated were used for the research.

Working parameters of the sowing unit for the seeder were placed in table 2 . They were within the range recommended by the producer.

Table 2.

Working parameters of the sowing unit of "MAX PNEUAMTIC" S 156 seeder

\begin{tabular}{lcc}
\hline $\begin{array}{l}\text { Set distance between seeds } \\
\text { in a row }(\mathrm{mm})\end{array}$ & $\begin{array}{c}\text { Working speed } \\
\left(\mathrm{km} \cdot \mathrm{h}^{-1}\right)\end{array}$ & $\begin{array}{c}\text { Sowing disc rotations } \\
\left(\mathrm{rot} \cdot \mathrm{min}^{-1}\right)\end{array}$ \\
\hline & 2.5 & 23 \\
30 & 3.0 & 27 \\
& 3.5 & 32 \\
& 4.0 & 37 \\
\hline
\end{tabular}

The radish seeds sowed at the investigated settings of working units of the seeder were falling into the moving adhesive belt of the test stand which simulates the section movement towards the soil surface. After the seeds were sown, at the set sowing parameters, distance between seeds at the distance of $1 \mathrm{~m}$ were measured in six iterations. Then, according to the standard ISO 7256/1-1984 (E) participation of single, double and empty sowings were determined. For single sown seeds, double sown seeds and empty sowings, seeds were qualified according to the relation:

- single sowing: $0,5 \cdot \mathrm{a}_{\text {sred }}<\mathrm{a} \leq 1,5 \cdot \mathrm{a}_{\text {sred. }}$.

- double sowing:a $\leq 0,5 \cdot \mathrm{a}_{\text {sred., }}$

- empty sowinga $\geq 1,5 \cdot a_{\text {sred. }}$

where:

$$
\begin{array}{ll}
\text { a } & - \text { distance between seeds in a row, (mm) } \\
\mathrm{a}_{\text {sred }} & - \text { average distance between seeds in a row, (mm) }
\end{array}
$$

Then, a percentage share of single, double and empty sowings that constitute a ratio of the number of specific shares of sowings to the general number of seeds sown on the measured distance was calculated.

Figure 2 presents a piece of the adhesive belt of the stand with sown seeds of radish. 
J. Kowalczuk et al.

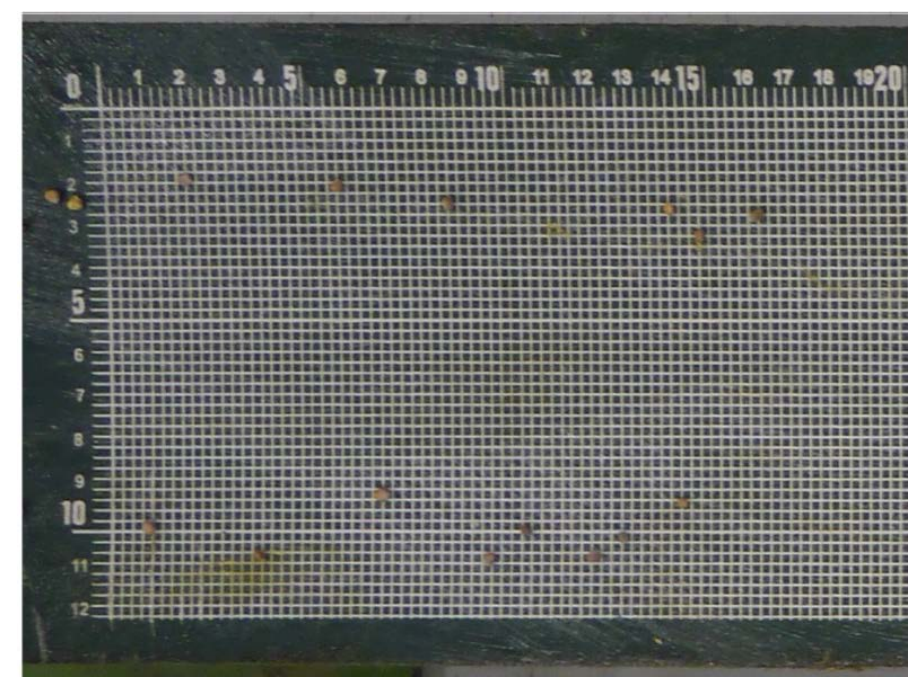

Figure 2. Piece of adhesive belt with seeds sown in two rows (scale in $\mathrm{mm}$ )

Results were subjected to statistical analysis. It was carried out based on the analysis of variance and T-Tukey's multiple confidence interval at $\alpha=0.05$.

\section{Research results}

Average research results of the unit from two sown rows were placed in figure 3 and results of their statistical analysis in table 3 .

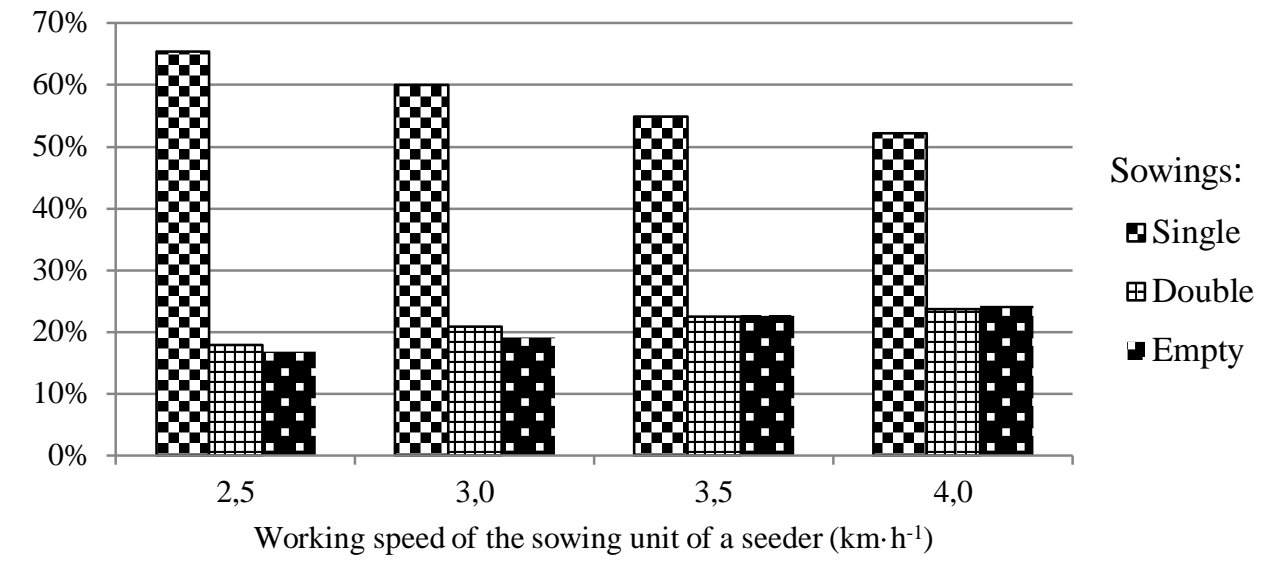

Figure 3. Impact of the working unit speed on the percentage share of single, double and empty sowings 
Assessment of sowing...

Table 3.

Participation of single, double and empty sowings of Saxa Polana radish at the investigated working speeds of seeder

\begin{tabular}{llll}
\hline \multirow{2}{*}{$\begin{array}{l}\text { Working speed } \\
\left(\mathrm{km} \cdot \mathrm{h}^{-1)}\right.\end{array}$} & \multicolumn{3}{c}{ Participation of sowing } \\
\cline { 2 - 4 } & Single & Double & Empty \\
\hline 2.5 & $0.65^{\mathrm{a}}$ & $0.18^{\mathrm{a}}$ & $0.17^{\mathrm{a}}$ \\
3.0 & $0.60^{\mathrm{a}, \mathrm{b}}$ & $0.21^{\mathrm{a}}$ & $0.19^{\mathrm{a}, \mathrm{b}}$ \\
3.5 & $0.55^{\mathrm{b}}$ & $0.23^{\mathrm{a}}$ & $0.22^{\mathrm{a}, \mathrm{b}}$ \\
4.0 & $0.52^{\mathrm{b}}$ & $0.24^{\mathrm{a}}$ & $0.24^{\mathrm{b}}$ \\
\hline
\end{tabular}

Various letters given in indexes mean that at the investigated working speeds of the seeder, statistically significant differences occurred between the percentage participation of single, double and empty sowing at the level of $\alpha=$ 0.05

For the set distance of $30 \mathrm{~mm}$ between the seeds in a row, the most favourable results concerning the share of single sowings (65 and 60\%) were determined at the sowing unit speed respectively within the range of 2.5 to $3.0 \mathrm{~km} \cdot \mathrm{h}^{-1}$. The increase of the speed above $3.0 \mathrm{~km} \cdot \mathrm{h}-1$ caused deterioration of the seeds sowing quality through statistically significant reduction of the single sowing participation and the increase of the empty sowings participation.

The statistical analysis of results proved significant differences between participation of single sowings obtained at the speeds of 2.5 and $3.5 \mathrm{~km} \cdot \mathrm{h}^{-1}, 2.5$ and $4.0 \mathrm{~km} \cdot \mathrm{h}^{-1}$, and they did not occur between the speeds of 2.5 and $3.0 \mathrm{~km} \cdot \mathrm{h}^{-1}$. Significant differences occurred also between participation of double sowings at all the investigated speeds and between participation of empty sowings at the speeds of 3.0 and $3.5 \mathrm{~km} \cdot \mathrm{h}^{-1}, 3.0$ and $4.0 \mathrm{~km} \cdot \mathrm{h}^{-1}$ and 3.5 and $4.0 \mathrm{~km} \cdot \mathrm{h}^{-1}$, and they occurred at the speeds of 2.5 and $4.0 \mathrm{~km} \cdot \mathrm{h}^{-1}$.

\section{Conclusions}

1. The most favourable research results concerning Saxa Polana radish seeds sowing quality with the working unit of "MAX PNEUAMTIC" S 156 seeder at the set distance between the seeds in a row amounting to $3.0 \mathrm{~cm}$ were obtained at the speed within 2.5 to $3.0 \mathrm{~km} \cdot \mathrm{h}^{-1}$. The growth of the speed above $3.0 \mathrm{~km} \cdot \mathrm{h}^{-1}$ caused deterioration of the sowing quality.

2. Due to the fact that the statistical analysis showed significant differences between participation of single sowing at the speed of $2.5 \mathrm{~km} \cdot \mathrm{h}^{-1}$ and 3.5 and $4.0 \mathrm{~km} \cdot \mathrm{h}^{-1}$, and did not show significant difference between results at the speeds of 2.5 and $3.0 \mathrm{~km} \cdot \mathrm{h}^{-1}$, the working speed within the range of 2.5 to $3.0 \mathrm{~km} \cdot \mathrm{h}^{-1}$ is recommended in case of sowing with "MAX PNEUAMTIC" S 156. 
J. Kowalczuk et al.

\section{References}

Banasiak, J., Michalak, J. (2000). Stanowiskowe badania jakości siewu punktowego nasion. Problemy Inżynierii Rolniczej, 4, 21-28.

Born, Z., Angelus, W., Dąbrowska, B., Doruchowski, R. W., Fajkowska, H., Gapiński, M., Glaser, T., Golcz, L., Kozłowska, M., Kryńska, W., Lewandowska, A., Małachowski, A., Nieć, H., Noszczyńska, K., Nowacka, W., Pudelski, T., Woyke H. (1982). Szczegółowa uprawa warzyw. Wyd. IV. PWRiL Warszawa.

Dobrowska-Kopecka, Z., Doruchowski, R. W., Gapiński, M. (1999). Warzywnictwo. PWRiL. Warszawa. ISBN 8309017049.

Gaikwad, B.B., Sirohi, N.P.S. (2008). Design of a low-cost pneumatic seeder for nursery plug trays. Biosystems Engineering, 99, 322-329.

International standard ISO 7256/1-1984 (E). (1984). Sowing equipment - test methods Part 1: Single seed drills.

Karayel, D., Barut, Z.B., Özmerzi, A. (2004). Mathematical Modelling of Vacuum Pressure on a Precision Seeder. Biosystems Engineering, 4, 437-444.

Kaur, T., Kumar, D. (2013): Design and development of calibration unit for precision planter. International Journal of Computer Science, Engineering and Applications, 3, 11-17.

Kołota, E., Orłowski, M., Biesiada, A. (2007). Warzywnictwo. Wyd. II poprawione i uzupełnione Wyd. UP. Wrocław. ISBN 9788360574171.

Markowski, P., Cejman, K., Rawa, T., Kaliniewicz, Z., Lipiński, A. (2012). Wpływ gęstości i prędkości siewu na rozmieszczenie nasion kukurydzy wysiewnych pneumatycznym siewnikiem precyzyjnym. Agricultural Engineering, (139), T.1, 235-245.

Nieć, H. (1984). Warzywa korzeniowe i rzepowate. PWRiL Warszawa. ISBN 8309008635

Przybył, J. (1997). Wplyw prędkości siewników punktowych na jakość siewu buraków cukrowych. Warszawa. Wyd. SGGW, 34-41.

Przybył, J., Błaszczak, P. (2000). Ocena jakości pracy siewników punktowych. Materiały z Jubileuszowej Międzynarodowej Konferencji Naukowej XXX lat Wydziału Techniki Rolniczej AR w Lublinie, nt.: „Aktualne problemy inżynierii rolniczej w aspekcie integracji Polski z Unią Europejską", Wyd. AR w Lublinie, Lublin 13-14 IX, 154-155.

Walczyk, J. (1992). Analiza możliwości uzupełniania przepustów nasion w siewniku do siewu punktowego. Zeszyty Problemowe. Postępów Nauk Rolniczych, 404, 273-279.

Yazgi, A., Degirmencioglu A. (2007). Optimisation of the seed spacing uniformity performance of a vacuum-type precision seeder using response surface methodology. Biosystems Engineering, 97, 3, 347-356.

Zhao, Z., Yaoming L., Jin Ch., Lizhang Xu. (2010). Numerical analysis and laboratory testing of seed spacing uniformity performance for vacuum-cylinder precision seder. Biosystems Engineering, 106, 344-351. 


\section{OCENA JAKOŚCI SIEWU NASION RZODKIEWKI SEKCJA ROBOCZA SIEWNIKA Z PNEUMATYCZNYM SYSTEMEM WYSIEWU}

Streszczenie. Celem badań była ocena jakości siewu nasion rzodkiewki sekcją wysiewającą siewnika „MAX PNEUAMTIC” S 156 z pneumatycznym (podciśnieniowym) systemem wysiewu. Badania przeprowadzono na stanowisku laboratoryjnym własnej konstrukcji. Wykazały one, że przy przyjętym do badań zakresie prędkości roboczej od 2,5 do $4,0 \mathrm{~km} \cdot \mathrm{h}^{-1}$ i obrotach tarczy wysiewającej od 23 do $37 \mathrm{obr} \cdot \mathrm{min}^{-1}$, najkorzystniejsze wyniki dotyczące dokładności rozmieszczenia nasion $\mathrm{w}$ rzędzie uzyskano przy prędkości w zakresie od 2,5 do $3,0 \mathrm{~km} \cdot \mathrm{h}^{-1}$. Wzrost prędkości powyżej $3,0 \mathrm{~km} \cdot \mathrm{h}^{-1}$ wpływał na pogorszenie jakości siewu nasion poprzez istotne statystycznie obniżenie udziału wysiewów pojedynczych oraz wzrost udziału przepustów.

Słowa kluczowe: nasiona, rzodkiewka, siew punktowy, jakość 